Skin Pharmacol 1997;10:314

\title{
Acknowledgments to Reviewers
}

The editor wishes to acknowledge with sincere appreciation the assistance of the many reviewers who have generously contributed their time and efforts during 1997 in the appraisal of manuscripts submitted to Skin Pharmacology. These reviewers not only have been of inestimable help in assessing the merit of original research articles but also, by their careful analysis and critique and their general and specific constructive recommendations, have often greatly enhanced the value of these manuscripts. The quality of the journal can be attributed in large measure to the quality of their effort. We are sincerely grateful.

Amon, U., Lübeck Bauer, R., Bonn Blume, U., Berlin Czarnetzki, B.M., Berlin Church, M.K., Southampton Czech, W., Freiburg De Leo, V., Rye, N.Y. Dowd, P., London Elmets, C, Cleveland, Ohio Fartasch, M., Erlangen Goerz, G., Düsseldorf Greaves, M.W., London Guy, R., San Francisco, Calif. Hadgraft, J., Cardiff Hegemann, L., Vienna Hunzelmann, N., Köln Jugert, F., Aachen Kerkhof, P.C.M., van de, Nijmegen Klaschka, F., Berlin Korting, H.C., Munich Kragballe, K., Aarhus Luger, A., Münster Mahrle, G., Köln Maibach, H., San Francisco, Calif.

Matern, S., Aachen

Mrowietz, U., Kiel

Niedner, R., Potsdam

Osieka, R., Aachen

Paus, R., Berlin

Proksch, E., Kiel

Ruzicka, T., Düsseldorf

Schaefer, H., Clichy

Schmutzler, W., Aachen

Stadler, R., Minden

Stüttgen, G., Berlin

Surber, C. Basel

Tronnier, H., Witten-Annen

Vorhees, J.J., Ann Arbor, Mich.

Wienert, V., Aachen

We also wish to thank the additional persons who have accepted to be part of our panel of referees but have yet to be solicited to review manuscripts.

AG, Basel 